\title{
ENTRETIEN AVEC LE CINÉASTE HASSANE MEZINE A PROPOS DU DOCUMENTAIRE “FANON: HIER, AUJOURD'HUI” 1
}

\author{
ENTREVISTA COM O CINEASTA HASSANE MEZINE SOBRE O \\ DOCUMENTÁRIO "FANON: YESTERDAY, TODAY"
}

Par Rosemere Ferreira da Silva ${ }^{2}$
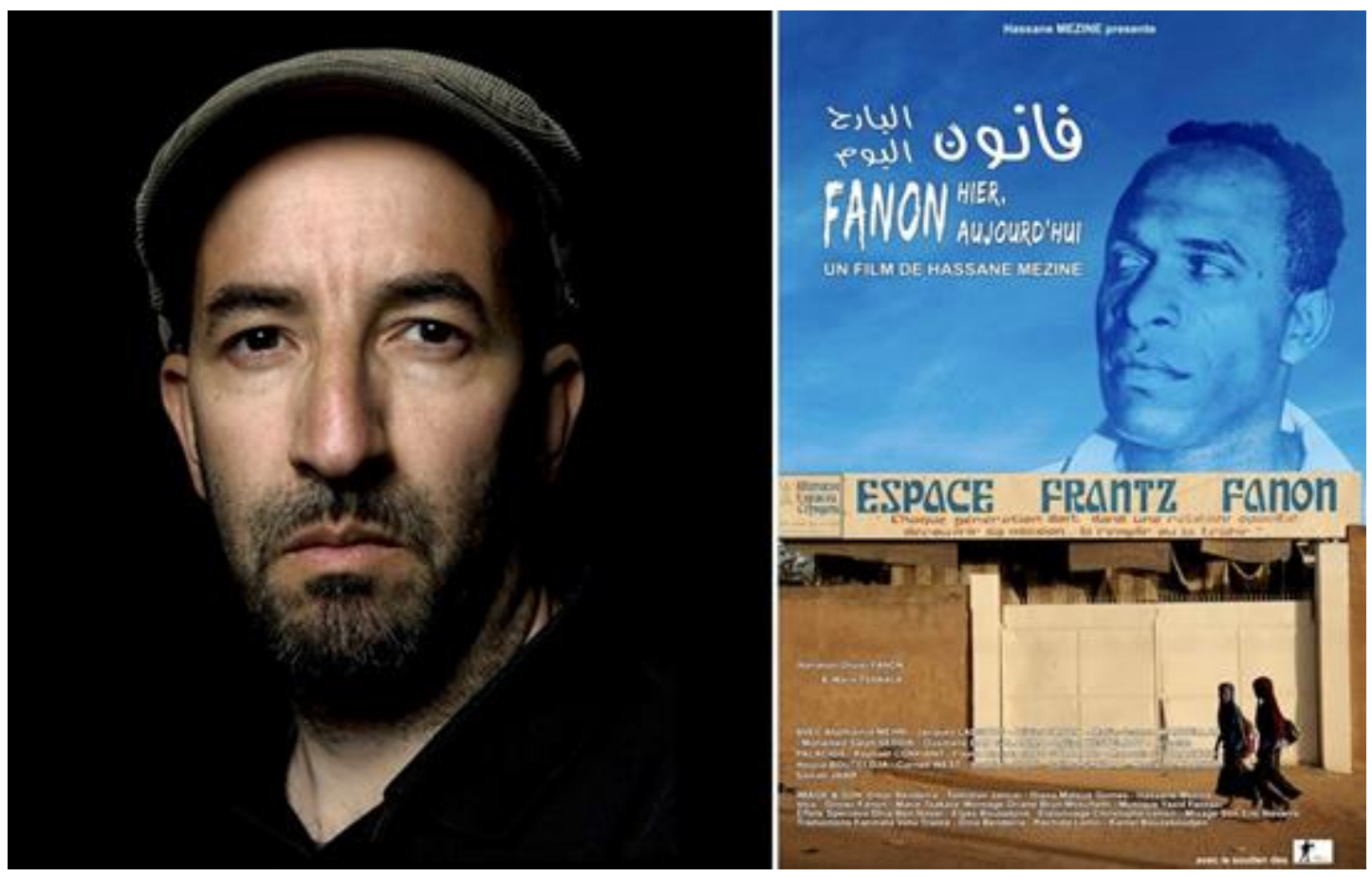

Hassane Mezine est un photographe et cinéaste algérien, né en 1972. En 2004, il a participé au tournage d'Algérie Twists / Turns, de Leila Morouche et Oriane Brun-Moschetti, et à la compagnie de René Vautier, cinéaste anticolonial. En 2015, il a lancé son premier documentaire, Fanon: hier, aujourd'hui. En 2016, il a travaillé comme directeur de la photographie dans Delou, une série télévisée de 52 épisodes réalisée au Niger en langue haoussa, réalisée par Souleymane Mahamane. L'entretien avec Hassane Mezine a résulté de notre rencontre avec le cinéaste dans le cours du Prof. Dr. Gordon, à l'UCONN, en 2019. A l'époque, Mezine nous présentait le documentaire Fanon: hier, aujourd'hui (Fanon: yesterday, today).

\footnotetext{
${ }^{1}$ Link to access movie information: https://pt.calameo.com/read/000127160bbeb23b028cc

2 Docente Titular do curso de Letras, Língua Portuguesa e Literaturas e do Mestrado Profissional em LetrasPROFLETRAS, do Departamento de Ciências Humanas- DCH- Campus V, da Universidade do Estado da Bahia (UNEB). E-mails: rosefsilva@uneb.br ou roserosefr2000@yahoo.com.br
} 


\section{Rosemere Ferreira: When did the idea of filming a documentary about Frantz Fanon begin? Why did you choose Fanon to be the central figure of your project?}

Hassane Mezine: L'idée m'était venu il y a quelques années de faire un documentaire sur cet illustre personnage, mais sans savoir vraiment comment et par où commencer. Lors d'une discussion avec un ami à ce sujet en 2014, il me dit qu'il a une interview d'un militant algérien qui a bien connu Fanon. Il ne savait pas quoi faire de cette entretien et me l'a donné. C'est à ce moment que l'aventure à commencé...

Je trouve très intéressant la dimension multiple de Fanon: il est psychiatre, militant anticolonialiste, théoricien de la décolonisation, mais également très engagé dans les luttes décoloniales. Il a connu de l'intérieur la condition de colonisé, ce qui n'est pas le cas, même si évidemment ce n'est pas de leur faute, de tous les militants anticolonialistes. Fanon occupe une position très particulière, il ausculte cliniquement le colonialisme, mais en même temps il propose des alternatives. Il ressent vivement l'oppression, mais il n'est jamais dans la haine, la rancœur ou l'esprit revanchard. Il l'exprime avec simplicité dans la conclusion des Damnés de la terre, quand il évoque «l'homme nouveau », il propose de soigner, de guérir tout le monde, tant ceux qui souffrent d'un complexe colonial de supériorité que ceux qui souffrent d'un complexe tout autant colonial d'infériorité. Sa vision est humaniste, inclusive: Fanon parle d'amour. Il propose sur cette base de recommencer sur des bases renouvelées et assainies une humanité nouvelle.

Rosemere Ferreira: How did your experience as a professional photographer and an educator in digital photography and multimedia guide the conception of the film?

Hassane Mezine: Cela a été une première expérience en tant que réalisateur sur un tel projet. Mon travail en tant que formateur à temps partiel m'a laissé du temps pour la relexion et la réalisation du film. Plus habitué au travail de reportage photographique, il m'a fallu trouver une approche différente qu'est celle du film documentaire. Il m'est malgré tout apparu nécessaire de donner une certaine importantce à l'image fixe tout au long du film, ma sensibilité de photographe a souvent orienté mes choix.

\section{Rosemere Ferreira: What are the main positive and negative aspects of producing a documentary film?}

Hassane Mezine: La réalisation est un exercice qui nécessite d'être en permanence en équilibre et trouver un accord juste entre l'image et le propos. Trouver les ressources, quelles soient budgétaires, humaines ou techniques n'a pas pu se faire sans difficultés. Il m'a fallu à chaque étape de la réalisation faire preuve d'imagination, voir prendre des risques afin de pouvoir diriger le documentaire et l'amener là où je voulais. 
S' engager dans ce type de projet de manière indépendante, vous oblige quelque part à devenir un homme orchestre et donc occuper plusieurs postes. Cela peut parfois être énergivore et stressant. Cela dit, j'ai pris beaucoup de plaisir à la réalisation et production de ce film

Rosemere Ferreira: Have you received different feedback on the film from audiences viewing it in cinemas, in community centers, and in universities? Do the audiences in each of those places engage in the same or in different ways?

Hassane Mezine: Les retours sont souvent très chaleureux. Les publics sont assez variés en effet, néanmoins les questions sont toujours très intéressantes. Il est vrai que les publics univzersitaires sont souvent des personnes averis ayant lu Fanon mais souvent avec une connaissance académique de la pensée fanonienne.

En revanche dans certaines rencontres non académiques, dans les publics touchés par différentes oppressions dont le racisme, beaucoup connaissent le nom de Fanon qui résonne chez eux sans pour autant pleinement connaître son parcours de militant, d'intellectuel et de psychiatre. Néanmoins, ce qui revient souvent c'est que Fanon exprime la réalité de leur vécu et donne un certaine légitimité à leurs propre réflexion.

Rosemere Ferreira: You were recently at the University of Connecticut (UCONN) discussing the film with graduate students in Professor Lewis R. Gordon's "Alienation and Freedom: Frantz Fanon's Philosophy of Human Science, Philosophy, Politics and Liberation" class. Could you describe the experience?

Hassane Mezine: Cela a été un honneur pour moi d'être invité par Lewis Gordon pour participer à ce séminaire de haute volée sur Frantz Fanon avec de Brillants étudiants. L'échange à été très intéressant. Croiser des contextes différents tels que celui des Etats-Unis, de la Colombie, du Brésil, de la France et d'ailleurs dans des discussions autour de Fanon m'a ramené à l'esprit du film lui même et sa diversité d'interventions venues des quatre coins du monde.

Rosemere Ferreira: "Fanon: Yesterday, Today" suggests that Frantz Fanon's thoughts as a writer, psychiatrist, activist, and revolutionary are still alive and relevant to understanding contemporary human relations. Perhaps the pre-eminent thinker of the 20th century on the issue of decolonization and the psychopathology of colonization, his works have inspired anti-colonial liberation movements for more than four decades. If Fanon were alive now, which struggle do you think would be the central focus of his work? 
Hassane Mezine: Dans le contexte actuel, Fanon peut rassembler les luttes globales du Sud, dans l'esprit de Bandung et créer des dynamiques d'alliance avec les combats dans le Nord développé. Je voulais précisément montrer que ses analyses peuvent éclairer les réalités contemporaines. Cette approche peut toujours être utile à des activistes ou à des universitaires, mais également à tout un chacun. Je souhaitais dans cet esprit montrer la dimension internationale de l'influence fanonienne.

Avec l'effondrement du bloc soviétique, la troisième voie, celle du Sud, est moins audible dans ce monde déboussolé ou les lois du marché sont les seules règles communes. Fanon peut réveiller les mémoires et les consciences.

On peut s'interroger à l'heure où de nombreux pays du Sud global se soulèvent quasi simultanément en Afrique, en Amérique du Sud, en Asie... Cela ne s'inscrit il pas dans la continuité des luttes pour des indépendances inachevées dont parlait Fanon?

Rosemere Ferreira: You invited intellectuals, activists, and Fanon's son to be part of the documentary. Among the many interesting people who had the opportunity to know Fanon, how you did you select who you would feature?

Hassane Mezine: La première partie du documentaire qui se veut être une biographie chronogéographique, s'est naturellement construite autour d'interviews de personnalités ayant connu personnellement Fanon et pouvant apporter un témoignage direct. Malheureusement, Il reste très peu de témoins de cette période, ayant côtoyé directement Frantz Fanon.

Pour la seconde partie, je tenais à mettre au premier plan différents acteurs qui se revendiquent de la pensée fanonienne et qui quelque part, à leur échelle prolongent l'héritage de luttes. Il a fallu faire des choix, des choix qui ont porté pour la majorité sur des acteurs de la société civile dont l'activité et l'engagement n'est plus à prouver. Il me semblait aussi important d'inscrire ce choix dans l'esprit de l'internationalisme de Fanon

Rosemere Ferreira: The audience at the University of Connecticut was really impressed by the beauty of the photographs of Fanon's wife, Josie Fanon, that were included in the film. What could you add about her life that is not part of the documentary? How can we understand her political activism as a woman from her time? Do you think her activism deserves a biographical work in its own right?

Hassane Mezine: Elle a été plus que sa muse ou inspiratrice. Elle aussi a combattu, a tenu à ses côtés un rôle fondamental. L'Algérie a été leur lien. Elle a retranscrit les livres de Fanon, a aussi joué les «passeuses », faisant circuler les manuscrits, vers l'équipe de son éditeur, Maspero ou vers un éditeur italien. On pensait qu'elle ignorait des aspects des activités de son mari, mais elle n'en ignorait rien. Après l'indépendance algérienne, elle jouera aussi un rôle en 
Afrique du Sud, soutenant activement l'ANC, également d'autres mouvements de libération africains qui avaient Alger pour base arrière.

En effet, son parcours, ce qui l'a amené à rejoindre la lutte des peuples opprimés, sa rupture avec le système coloniale mériteraient un travail de recherche biographique plus détaillé!

Rosemere Ferreira: You have been travelling across Europe, North Africa, the Francophone Caribbean, and the United States of America to screen the documentary. How do you characterize the impact of the film in those different places?

Hassane Mezine: Lors de tous ces déplacements J'ai pu ressentir le même enthousiasme et la même énergie à l'issue de chaque projection. A chaque fois des spectateurs ont exprimé la volonté de se plonger ou de se replonger dans les écrits de Fanon.

J'ai été trés surpris de voir à quel point, que ce soit sur les trois continents, la manière dont le public se sentait galvanisé par le film, se sentant conforté dans ses engagements et parfois sucitait l'engagement.

Rosemere Ferreira: Considering the delicate political moment in South America, especially in Brazil, related to the frequent and concerted attacks on democracy and human rights, what kind of message does the film offer to those countries?

Hassane Mezine: La situation dans le Sud Global, au Brésil comme en Equateur, en Algérie, au Liban ou au Chili nous montre le vrai visage de la logique chaotique de l'ultra libéralisme et l'avenir sombre qu'il nous promet. Fanon disait "When we revolt it's not for a particular culture. We revolt simply because, for many reasons, we can no longer breathe."

Le film offre la possibilité de se questionner sur notre capacité à sortir ensemble de ce système destructeur et rendre possible un monde de respect entre les hommes au travers de la lutte pour la dignité et la liberté.

Rosemere Ferreira: What are your future plans as a photographer, filmmaker, or both? Are you planning to direct another documentary? Who would be the central figure of the next project and why?

Je n'ai pas encore de visibilité certaine sur mes futurs projets, qu'ils soiet photographiques ou cinématographiques. Néanmoins je suis ceratins d'une chose, c'est qu'ils seront toujours animés par un esprit de lutte et de justice fanonien. 
Rosemere Ferreira: In Black Skin, White Masks, Frantz Fanon wrote: "What matters is not to know the world but to change it." How do you understand the kind of positive change that photography and cinema can make?

Hassane Mezine: La photographie tout comme le cinéma ou l'art en général peuvent être un vecteur de reflexion et d'éducation populaire. Je ne parle pas ici d'art bourgeois, mais d'art accessible à tous. Le but de ce film est de rendre accessible à tous la pensée de Fanon et non pas de la confiner à des milieux uniquement universitaires.

Rosemere Ferreira: Hassane, could you please send a link to an excerpt of the film that I can include at the end of the interview. The trailer would be fine, though I prefer the part where Fanon is walking. 